\title{
KESULITAN MAHASISWA DALAM MENULIS TEKS EKSPOSISI: ANALISIS BERBASIS GENDER
}

\section{STUDENTS' DIFFICULTIES IN WRITING EXPOSITORY TEXT: A GENDER-BASED ANALYSIS}

\author{
Atik Umamah, Ika Hidayanti, Kurniasih \\ Fakultas Keguruan dan IImu Pendidikan, Universitas Islam Malang \\ E-mail: atikumamah@unisma.ac.id, ikahidayanti@unisma.ac.id \\ kurniasih@unisma.ac.id
}

Naskah diterima tanggal: 31-12-2018 disetujui tanggal: 26-02-2019

\begin{abstract}
This research aims to 1) identifying English students' problems in writing expository text, 2) examining the significant difference of the difficulties confronted by the students in terms of gender, and 3) describing the difficulties in writing based on the students' writings. This research applied quantitative approach. Descriptive statistic was to identify the students' writing difficulties, and t-test was to measure whether the problems faced by male and female students were significantly different. Further, qualitative analysis was used to describe the students' writing problems based on their writings. The subjects (26 students of class $2 A$ academic year 2016/2017) were assigned to respond questionnaire containing of problems in four aspects of writing: content and organization, grammar, mechanics, and style. Furthermore, six students' writings were analyzed to gain a real picture of their difficulties. The statistical analysis revealed that grammar was the main problem in writing. Related to gender, it was found that the difference was not significant. Contrastive analysis of students' writings and questionnaire prove that the students recognize their problems in writing. These findings are in line with previous studies. To help the students cope with writing difficulties, teacher needs to train them with writing strategies by implementing strategies based instruction.
\end{abstract}

Keywords: writing skill, writing aspects, writing problems, gender, expository text

Abstrak: Tujuan penelitian ini adalah untuk (1) mengidentifikasi kesulitan mahasiswa jurusan Pendidikan Bahasa Inggris dalam menulis teks eksposisi, (2) mengetahui signifikansi perbedaan kesulitan yang dihadapi mahasiswa berdasarkan gender, dan (3) mendeskripsikan kesulitan menulis yang dihadapi mahasiswa berdasarkan hasil pekerjaan mereka. Penelitian ini menggunakan pendekatan kuantitatif. Statistik deskriptif digunakan untuk mengidentifikasi kesulitan mahasiswa dalam menulis, dan uji t untuk mengukur apakah kesulitan yang dihadapi mahasiswa laki-laki dan perempuan berbeda secara signifikan. Analisis kualitatif digunakan untuk menggambarkan kesulitan menulis berdasarkan hasil pekerjaan mahasiswa. Subjek penelitian adalah mahasiswa angkatan 2016/2017 kelas 2A berjumlah 26 mahasiswa. Data dikumpulkan melalui penyebaran angket yang berisi kesulitan yang dialami mahasiswa dalam empat aspek menulis: content and organization, grammar, mechanics, dan style. Selain itu, enam hasil pekerjaan subjek dianalisis untuk memperoleh gambaran kesulitan yang mereka hadapi. Hasil analisis statistik menunjukkan bahwa secara keseluruhan kesulitan yang dihadapi mahasiswa adalah dalam aspek grammar. Terkait dengan gender, perbedaan kesulitan di antara dua kelompok tidak signifikan. Contrastive analysis dari hasil pekerjaan subjek dan respon mereka terhadap kuesioner membuktikan bahwa subjek mengetahui kesulitan yang mereka hadapi dalam proses menulis. Temuan 
penelitian ini mendukung temuan penelitian terdahulu. Untuk membantu mahasiswa mengatasi kesulitan dalam menulis, dosen perlu mengajarkan mereka strategi menulis dengan mengimplementasikan strategies-based instruction.

Kata kunci: keterampilan menulis, aspek menulis, kesulitan dalam menulis, gender, teks eksposisi

\section{PENDAHULUAN}

Menulis merupakan keterampilan yang membutuhkan proses kognitif sekaligus proses interaksi sosial untuk mengekspresikan ide dan berbagi ide dengan pembaca (Munoz-Luna, 2015). Menurut Canagarajah (dalam Raoofi, Binandeh \& Rahmani, 2017), menulis memiliki lima karakteristik dasar yang menonjol yaitu 1) menulis merupakan proses merefleksikan dan menciptakan realitas; 2) menulis merupakan aktivitas interaksi sosial antara penulis dan pembaca dalam ruang dan waktu tertentu; 3) tulisan dibuat berdasarkan negosiasi antara penulis dan sumber menulis yang tersedia dalam satu konteks; 4) menulis memberikan kesempatan bagi penulis untuk menyampaikan keyakinan ideologis, untuk mengekspresikan diri, dan untuk memberikan nilai entitas melalui teks; dan 5) menulis merupakan proses historis yang dinamis dimana ide, perjuangan, konflik, dan konsep dari sebuah teks terbuka untuk komentar dan sudut pandang dari penulis maupun pembaca.

Keterampilan ini menjadi sangat kompleks terutama bagi mahasiswa Indonesia di mana Bahasa Inggris dipelajari sebagai bahasa asing (English as a foreign language). Kaplan (dalam Brown, 2007) berpendapat, penulis yang berasal dari negara Asia (oriental) cenderung berpikir spiral. Mereka cenderung menulis tidak langsung pada poin intinya melainkan sedikit berputarputar dalam menyampaikan ide pokok.

Selain faktor budaya, ada beberapa faktor lain yang menyebabkan menulis menjadi keterampilan yang lebih kompleks. Di antara faktor tersebut adalah proses menulis yang panjang meliputi pramenulis (pre-writing), mengorganisasi ide (organizing), menulis draf (drafting/writing), memperbaiki draf (polishing), dan memublikasikan (publishing) (Hogue, 2008). Pre-writing merupakan langkah awal untuk mendapatkan ide sesuai dengan topik yang telah ditentukan. Proses ini sering kali menyulitkan mahasiswa karena kurangnya pengetahuan (background knowledge) tentang topik yang harus ditulis. Hal ini disebabkan minat baca yang rendah. Temuan dari penelitian (Schoonen, 2018; Jennifer \& Ponniah, 2018; Aminullah \& Sahidol, 2016) membaca dan menulis memiliki korelasi yang signifikan. Semakin banyak membaca, semakin baik pula kualitas tulisan. Hal ini dikarenakan melalui proses membaca, mahasiswa mendapatkan pemahaman tentang bagaimana mereka menulis dengan baik dan pengetahuan/ide yang mungkin menjadi topik tulisan mereka (Brown, 2007).

Langkah berikutnya adalah memilih dan memilah serta menyusun ide yang sudah didapatkan dalam bentuk kerangka karangan (organizing). Kerangka karangan tersebut dikembangkan dalam bentuk draf kasar (writing draft). Pada proses ini, penulis hanya fokus menuangkan ide tanpa memperhatikan teknis penulisan. Untuk memperbaiki tulisan (polishing) terdiri dari dua tahap yaitu merevisi konten (revising) dan memperbaiki hal-hal yang berkaitan dengan grammar dan mechanics seperti penggunaan huruf kapital, tanda baca, dan ejaan (editing). Langkah terakhir adalah menulis draf akhir (final copy) sebelum tulisan dikumpulkan atau dipubikasikan.

Brown (2007) berpendapat bahwa untuk menghasilkan tulisan yang berkualitas diperlukan pemahaman tentang struktur teks (generic structure), pemahaman retoris (rhetoric knowledge), dan pengetahuan tata bahasa 
(grammar knowledge). Struktur teks umumnya bergantung pada jenis teks yang dibuat. Misalnya, jenis teks deskripsi akan memiliki dua struktur utama yaitu identifikasi (identification) dan deskripsi (description). Akan tetapi, dalam menulis paragraf menurut Oshima dan Hogue (2007) lazimnya terdapat tiga komponen yang harus ada yaitu kalimat berisi topik/ide pokok (topic sentence), kalimat penjelas (supporting sentences), dan kesimpulan (conclusion). Pemahaman retorik berkaitan dengan pemahaman tentang aspek kohesi dan koherensi, sedangkan pemahaman tata bahasa berkaitan langsung dengan penggunaan tenses, kesesuaian subjek dan kata kerja, penggunaan kata depan (preposition), modal, dan sebagainya.

Dalam keterampilan menulis ada beberapa jenis teks yang harus dipelajari seperti narasi, deskripsi, recount, argumentasi, opini, eksposisi dan sebagainya. Setiap jenis teks memiliki generic structure yang tidak sama sehingga pemahaman tentang generic structure dari setiap genre mutlak diperlukan. Seperti halnya jenis teks yang lain, teks eksposisi mengharuskan mahasiswa memiliki pemahaman tentang struktur teks (generic structure), pemahaman retoris (rhetoric knowledge), dan pengetahuan tata bahasa (grammar knowledge). Jenis teks eksposisi memiliki tingkat kompleksitas yang lebih tinggi dibandingkan dengan jenis teks lain. Jenis tulisan ini memerlukan background knowledge karena berkaitan dengan topik yang update dan membutuhkan data real untuk mendukung argumen yang disampaikan. Selain itu, tone tulisan jenis teks ini cenderung formal sehingga membutuhkan kosa kata yang kurang familiar bagi mahasiswa.

Adapun aspek yang sering digunakan untuk menilai sebuah tulisan terdiri dari empat yaitu konten dan organisasi (content and organization), tata bahasa (grammar), mekanik (mechanics), dan gaya bahasa (style) (Oshima \& Hogue, 2007). Pada aspek konten dan organisasi, tulisan akan dinilai berdasarkan kesesuaian isi dengan topik dan pengembangan ide serta kelengkapan komponen dalam teks seperti judul, kalimat topik, kalimat penjelas, dan kesimpulan. Tata bahasa adalah penilaian terhadap penggunaan tense, modal, preposisi, artikel, kelengkapan subjek dan kata kerja dan sebagainya. Mekanik adalah aspek penilaian yang berkaitan dengan penggunaan huruf besar, tanda baca, dan ejaan. Aspek terakhir yaitu gaya bahasa berkaitan dengan penggunaan kalimat yang bervariasi, kosa kata (vocabulary) yang tepat, serta penggunaan idiom.

Karena faktor tersebut mahasiswa terutama di konteks Bahasa Inggris sebagai bahasa asing (English as a Foreign Language/EFL) mengalami kesulitan dalam menulis. Hal ini dapat diketahui dari publikasi beberapa penelitian di beberapa negara seperti di Arab Saudi (Javid, Farooq, \& Umer, 2013; Mohammad \& Hazarika, 2016), di Bangladesh (Karim, Maasum, \& Latif, 2017), di Oman (Al Seyabi \& Tuzlukova, 2014), di Pakistan (Fareed, Ashraf, \& Bilal, 2016), dan di Indonesia (Ariyanti, 2016).

Di Arab Saudi, kesulitan tersebut antara lain dalam hal mekanik seperti penggunaan huruf besar, tanda baca, tata bahasa (grammar) dan penulisan ejaan (Mohammad \& Hazarika, 2016). Sedangkan menurut temuan penelitian Javid, Farooq, dan Umer (2013), mahasiswa mengalami masalah serius dengan leksikal, organisasi ide, dan grammar. Sedangkan mahasiswa Bangladesh mengalami kesulitan dalam menggunakan idiom, kosakata yang tepat, dan antonim (Karim, Maasum, \& Latif, 2017). Mahasiswa di Oman juga mengalami kesulitan terkait dengan masalah leksikal dan aspek konten (Al-Seyabi \& Tuzlukova, 2014). Di Indonesia, masalah penggunaan tata bahasa (grammar) dan perbedaan latar belakang budaya (cultural background) menjadi hal yang menyulitkan mahasiswa dalam menulis (Ariyanti, 2016). 
Berdasarkan temuan penelitian tersebut, kesulitan dalam menulis dapat diklasifikasikan menjadi beberapa aspek seperti tata bahasa (grammar), mekanik (ejaan, penggunaan huruf besar, tanda baca), leksikal (penggunaan kosa kata, antonim), dan konten. Selain itu, Yahya dan Hashim (2013) membagi kesulitan dalam menulis ke dalam beberapa kategori: pemahaman dan konsepsi ide (comprehension and conception of ideas), komposisi (composition), akurasi dan ketepatan bahasa (language accuracy and appropriacy), kosa kata (vocabulary), dan kurangnya waktu (lack of time). Temuan penelitian tersebut dengan jelas mengindikasikan bahwa menulis dalam konteks EFL merupakan skill yang perlu mendapat perhatian lebih.

Kesulitan dalam menulis sering kali juga dikaitkan dengan gender di mana laki-laki dianggap cenderung lebih mengalami kesulitan dibandingkan perempuan (Bijami, Kashef, \& Khaksari, 2013). Kesimpulan yang sama juga disampaikan oleh Ong (2015) bahwa mahasiswa perempuan memiliki nilai tes menulis lebih baik dibandingkan mahasiswa laki-laki. Hal ini kembali menunjukkan bahwa mahasiswa laki-laki cenderung paling rentan mengalami kesulitan dalam menulis. Meskipun demikian, tidak banyak penelitian yang secara spesifik mengeksplorasi kesulitan menulis berdasarkan gender. Beberapa di antaranya dilaporkan oleh Javid, Farooq, dan Umer (2013) dan Hamid, Ariani, dan Ariyanto (2013). Akan tetapi kedua penelitian tersebut memiliki hasil yang tidak konsisten. Menurut Javid, Farooq, dan Umer (2013) perbedaan dalam kesulitan menulis berdasarkan gender tidak signifikan. Sementara itu, hal berbeda dilaporkan oleh Hamid, Ariani, dan Ariyanto (2013) yang menemukan bahwa mahasiswa laki-laki jauh lebih banyak mengalami kesulitan dalam menulis dibandingkan mahasiswa perempuan.

Dengan demikian, hasil penelitian terkait dengan kesulitan menulis berdasarkan gender masih belum meyakinkan dan belum bisa digeneralisasi. Penelitian ini perlu dilakukan untuk medapatkan pemahaman lebih terkait dengan kesulitan mahasiswa dalam menulis dilihat dari sisi perbedaan gender. Adapun pertanyaan penelitian ini adalah 1) kesulitan apa yang paling sering dihadapi mahasiswa dalam menulis teks eksposisi? 2) adakah signifikansi perbedaan kesulitan menulis teks eksposisi antara mahasiswa laki-laki dan perempuan?, dan 3) bagaimana deskripsi kesulitan mahasiswa dalam menulis teks eksposisi berdasarkan hasil pekerjaan mahasiswa?

Tujuan dari penelitian ini adalah untuk mendapatkan gambaran komprehensif kesulitan mahasiswa dalam menulis teks eksposisi dan signifikansi perbedaan kesulitan menulis berdasarkan gender. Adapun aspek menulis yang akan dijadikan landasan teori dalam mengidentifikasi kesulitan mahasiswa diadaptasi dari Oshima dan Hogue (2007) terdiri dari empat aspek: organization and content, grammar, mechanics, dan style. Berdasarkan temuan penelitian ini, strategi belajar yang tepat untuk mengatasi permasalahan dalam menulis teks eksposisi dapat diberikan. Dengan demikian mahasiswa bisa menulis jenis teks ini dengan konten dan organisasi yang baik, tata bahasa yang tepat, mekanik (tanda baca, penggunaan huruf kapital, ejaan) yang benar, dan gaya bahasa yang baik.

\section{METODE}

Penelitian ini menggunakan pendekatan kuantitatif dengan analisis secara kuantitatif dan kualitatif. Analisis kuantitatif berupa statistik deskriptif digunakan untuk menjawab pertanyaan penelitian pertama yaitu mengidentifikasi kesulitan mahasiswa dalam menulis teks eksposisi. Sedangkan pertanyaan kedua dijawab melalui analisis komparatif melalui uji t untuk mengukur apakah kesulitan yang dihadapi mahasiswa laki-laki dan perempuan berbeda secara signifikan. Sedangkan analisis kualitatif diperlukan untuk menggambarkan kesulitan 
menulis yang dihadapi mahasiswa berdasarkan hasil pekerjaan atau produk tulisan mereka.

Penelitian ini melibatkan mahasiswa angkatan 2016/2017 kelas 2A yang berjumlah 26 mahasiswa yang terdiri dari 20 perempuan (77\%) dan 6 laki-laki (23\%). Subjek penelitian ini ditentukan berdasarkan purposive sampling karena hanya kelas ini yang paling memungkinkan untuk diteliti.

Data dikumpulkan dengan menyebarkan angket berisi 22 butir yang berisi kesulitan yang dialami mahasiswa dalam empat aspek menulis: content and organization, grammar, mechanics, dan style. Angket ini diadaptasi dari writer's checklist Oshima dan Hogue (2007) dengan respon berupa Likert-scale dari skala 1-5 ( 1 berarti tidak pernah mengalami kesulitan, 2 jarang mengalami kesulitan, 3 kadang-kadang mengalami kesulitan, 4 sering mengalami kesulitan, dan 5 selalu mengalami kesulitan). Selain itu, data juga diperoleh dari hasil pekerjaan 6 subjek (3 laki-laki dan 3 perempuan) yang digunakan sebagai data kualitatif. Data kemudian dianalisis dengan deskriptif statistik untuk mengetahui nilai rata-rata kesulitan dan t-test untuk mengetahui tingkat signifikansi perbedaan kesulitan yang dihadapi mahasiswa laki-laki dan perempuan. Data dari pekerjaan subjek kemudian dianalisis secara terperinci untuk menggambarkan dengan jelas kesulitan menulis pada tiap aspek. Dengan contrastive analysis kemudian sampel tulisan mahasiswa dianalisis untuk mengungkap lebih mendalam kesalahan apa saja yang mereka buat ketika menulis dan apakah ini merefleksikan jawaban mereka pada saat mengisi kuesioner.
Keterbatasan penelitian ini adalah jumlah subjek yang mengisi kuesioner hanya satu kelas (26 mahasiswa) sehingga temuan penelitian ini belum bisa digeneralisasikan. Kuesioner yang digunakan merupakan adaptasi dari writer's checklist Oshima dan Hogue (2007) yang pertanyaannya kurang detail terutama pada setiap aspeknya. Selain itu, hasil pekerjaan mahasiswa yang dianalisis merupakan draf akhir yang sudah melalui proses revisi tiga kali sehingga kesalahan yang ditemukan tidak merefleksikan kesulitan yang sesungguhnya dialami mahasiswa.

\section{HASIL DAN PEMBAHASAN}

Penelitian ini difokuskan untuk menginvestigasi tiga hal yaitu 1) kesulitan mahasiswa dalam menulis teks eksposisi, 2) perbedaan kesulitan yang dialami mahasiswa dilihat dari sisi gender, dan 3) deskripsi hasil pekerjaan subjek dalam menulis teks eksposisi.

\section{Identifikasi Kesulitan Mahasiswa dalam Menulis Teks Eksposisi}

Hasil dari analisis statistik (Tabel 1) menunjukkan bahwa grammar masih menjadi masalah klasik bagi mahasiswa Indonesia dalam menulis termasuk dalam teks dengan genre eksposisi. Kesulitan berikutnya secara berurutan adalah dalam hal mechanics, organization and content, dan style.

Dilihat dari nilai rata-rata pada setiap aspek, grammar dengan nilai rata-rata 3,5288 berada di urutan pertama. Dengan rata-rata 3,3769, mechanics berada di posisi kedua. Selisih nilai antara grammar dan mechanics tidak jauh

Tabel 1 Statistik Deskriptif

\begin{tabular}{llc}
\hline Aspek Menulis & Rata-rata & Urutan \\
\hline Grammar & 3,5288 & 1 \\
Mechanics & 3,3769 & 2 \\
$\begin{array}{l}\text { Organization } \\
\text { Content }\end{array}$ & 3,0812 & 3 \\
Style & 2,4231 & 4 \\
\hline
\end{tabular}


berbeda, hanya terpaut 0,1519 . Hal ini menunjukkan bahwa dua aspek menulis tersebut merupakan aspek yang paling menyulitkan mahasiswa dalam menulis teks eksposisi. Sementara itu, di posisi ketiga adalah content and organization yang mendapatkan nilai ratarata 3,0812. Nilai ini terpaut cukup jauh dari dua aspek sebelumnya dan dari aspek terakhir yaitu style dengan nilai rata-rata 2,4231. Style merupakan aspek dengan nilai rata-rata terendah dan di bawah 3 yang mengindikasikan bahwa style bukanlah masalah krusial yang dihadapi mahasiswa dalam menulis jenis teks eksposisi.

Berdasarkan temuan di atas, bisa dikatakan bahwa kesulitan mahasiswa masih terfokus pada unsur keakuratan bahasa (language accuracy) dalam hal grammar dan mechanics. Temuan bahwa grammar menjadi sumber utama kesulitan bagi mahasiswa dalam menulis tidaklah mengejutkan karena temuan ini sesuai dengan temuan beberapa penelitian terdahulu (Al Seyabi \& Tuzlukova, 2014; Wigati, 2014; Ariyanti, 2016; Fareed, Ashraf \& Bilal, 2016).

Kesalahan paling sering muncul pada aspek grammar adalah penggunaan kata depan (preposition), kelengkapan kata kerja terutama dalam bentuk kalimat negatif tidak ada kata kerja bantu, kesesuaian subjek dan kata kerja, kata benda tunggal/jamak, penggunaan gerund dan infinitive, pola tenses, dan penggunaan kata hubung. Hal ini mengindikasikan bahwa mahasiswa belum memiliki pemahaman grammar yang baik, terutama dalam hal yang paling mendasar dalam menulis kalimat yang lengkap. Ini sesuai dengan temuan Wigati (2014) bahwa mahasiswa dengan level dasar cenderung bermasalah dengan grammar. Untuk membantu mahasiswa mengatasi masalah grammar, dosen bisa mengarahkan mahasiswa untuk menggunakan strategi yang fokus pada bahasa (language focus strategies) dengan memberikan penjelasan tentang struktur kalimat secara eksplisit maupun implisit. Selain itu, cognitive strategies dengan menganalisis kata dengan mengelompokkan kelas kata dan mempelajari pola kalimat dalam Bahasa Inggris juga bisa digunakan untuk mengurangi kesalahan grammar (Mistar, Zuhairi \& Parlindungan, 2014).

Yang menarik adalah ternyata aspek mechanics yang berkaitan dengan penggunaan huruf besar, tanda baca, dan ejaan menempati posisi kedua. Ini sesuai dengan hasil penelitian Mohammad dan Hazarika (2016). Berdasarkan analisis hasil pekerjaan mahasiswa ditemukan bahwa kesalahan terbanyak pada tanda baca dengan total 13 kesalahan. Penggunaan huruf besar (4 kesalahan) dan ejaan (2 kesalahan) berada pada posisi berikutnya. Hal ini mengimplikasikan kurangnya pemahaman mahasiswa akan pentingnya penggunaan tanda baca dan kurangnya ketelitian dalam menulis. Untuk mengatasi kesulitan dalam hal mechanics, mahasiswa sebaiknya diarahkan untuk menerapkan social strategies antara lain dengan menerapkan proofreading (meminta teman membaca tulisan dan memberikan saran) MunozLuna, 2015; Mistar, Zuhairi \& Parlindungan, 2014).

Aspek organization and content menempati posisi ketiga dengan nilai rata-rata yang cukup tinggi $(3,0812)$. Hal ini menandakan bahwa mahasiswa juga mengalami kesulitan dalam mengembangkan dan mengorganisasi ide dengan baik. Al Seyabi dan Tuzlukova (2014) juga menemukan hal serupa pada mahasiswa di Oman. Kesulitan pada aspek ini tercermin dari tulisan mahasiswa yang masih kurang lengkap dalam memberikan supporting details. Selain itu, ada pula ide yang ditulis berulang. Hasil tulisan yang dianalisis merupakan draf akhir yang sudah beberapa kali dikonsultasikan melalui proses writing conference (konsultasi langsung dengan dosen) dan peer review (saling mengoreksi antarmahasiswa) sehingga kesalahan pada aspek ini tidak banyak ditemukan. Jika hasil pekerjaan yang dianalisis adalah draf awal sebelum dikonsultasikan, bisa jadi kesalahan 
pada aspek organization and content jauh lebih banyak. Meskipun demikian, aspek menulis ini tetap mendapatkan nilai rata-rata kesulitan menulis cukup tinggi. Hal ini menunjukkan bahwa organization and content merupakan aspek menulis yang tidak mudah. Untuk mengurangi kesulitan pada aspek ini, beberapa temuan penelitian (Raoofi, Binandeh \& Rahmani, 2017; Munoz-Luna, 2015) membuktikan bahwa metacognitive strategies merupakan strategi yang tepat. Strategi ini dilakukan dengan membuat perencanaan dalam menulis (mulai dari proses menemukan ide hingga proses menulis) dan memonitor progress tulisan mereka.

Kesulitan dengan nilai mean terendah adalah style atau gaya dan variasi dalam menulis yang meliputi vocabulary (diksi) terdapat 4 kesalahan, penggunaan idiom, dan gaya kalimat. Karim, Maasum, dan Latif (2017) juga menemukan bahwa masalah ini dihadapi oleh mahasiswa Bangladesh. Dalam penelitian ini, aspek yang mendapatkan nilai mean terendah bisa disebabkan karena topik yang ditulis mahasiswa adalah "Penggunaan Edmodo dalam Matakuliah. Menulis" yang istilah teknisnya tidak terlalu asing bagi mahasiswa yang terbiasa menggunakan gadget dan aplikasi online sehingga mereka tidak mengalami hambatan yang berarti dalam hal penggunaan vocabulary. Selain itu, jenis teks eksposisi memiliki tone yang cenderung formal sehingga tidak terlalu membutuhkan penggunaan idiom. Hanya saja, gaya menulis mereka masih cenderung menggunakan gaya dalam Bahasa Indonesia atau hanya menerjemah secara literal saja. Kesulitan ini dapat dikurangi dengan mendorong mahasiswa untuk lebih sering membaca teks dalam Bahasa Inggris yang otentik (yang ditulis oleh penulis asli Bahasa Inggris/native writer) dan memberikan contoh teks Bahasa Inggris sebelum mereka diberi tugas untuk menulis. Menurut temuan dari beberapa penelitian (Schoonen, 2018; Jennifer \& Ponniah, 2018; Aminullah \& Mohd Sahidol, 2016) membaca dan menulis memiliki korelasi yang signifikan. Melalui proses membaca teks otentik, mahasiswa mendapatkan pemahaman tentang bagaimana menulis dalam Bahasa Inggris dengan baik dan benar sesuai dengan struktur dan gaya yang dipakai penulis asli Bahasa Inggris (native writer). Selain itu, dengan membaca mereka mendapatkan pengetahuan/ide untuk dijadikan topik tulisan mereka (Brown, 2007).

Hasil di atas menunjukkan bahwa pada dasarnya mahasiswa menyadari dan mengetahui kesulitan yang mereka hadapi ketika menulis teks eksposisi. Hal ini sedikit berbeda dengan kesimpulan Mohammad \& Hazarika (2016) bahwa mahasiswa Arab melakukan kesalahan dalam menulis namun tidak menyadarinya. Meskipun mahasiswa yang menjadi subjek penelitian ini menyadari kesalahannya, mereka masih belum bisa mengatasi masalah tersebut. Pada titik ini, strategi belajar yang tepat sangat diperlukan. Strategi belajar memberikan efek positif terhadap kesuksesan belajar bahasa (Mistar, 2011)

Secara umum, menurut He, Chang, dan Eileen Chen (2011), strategi yang digunakan mahasiswa yang memiliki kualitas menulis yang baik antara lain monitoring atau evaluating, revising, dan compensating. Sedangkan menurut Raoofi, Binandeh, dan Rahmani (2017), strategi metacognitive, cognitive, affective and effort regulation adalah strategi yang paling sering digunakan oleh mahasiswa dengan keterampilan menulis yang baik.

Oleh karena itu, peran dosen menjadi sangat krusial dalam membimbing dan mengarahkan mahasiswa dalam memilih dan menggunakan strategi menulis yang tepat. Temuan penelitian Okasha dan Hamdi (2014), strategies-based instruction terbukti dapat meningkatkan keterampilan menulis. 


\section{Perbedaan Kesulitan yang Dialami Maha- siswa Dilihat dari Sisi Gender}

Tabel 2 menggambarkan hasil analisis t-test yang mengindikasikan bahwa perbedaan kesulitan yang dihadapi mahasiswa laki-laki dan perempuan dalam menulis teks bergenre eksposisi tidak signifikan. Sebagaimana ditunjukkan pada tabel, nilai $t$ lebih dari level of significant $(, 05)$. Ini mengindikasikan bahwa baik mahasiswa laki-laki maupun perempuan menghadapi permasalahan menulis yang tidak jauh berbeda.

Temuan penelitian ini menunjukkan bahwa berdasarkan gender kesulitan yang dialami subjek tidak berbeda secara signifikan. Hal ini sejalan dengan temuan penelitian Umamah dan Hidayanti, 2018; Javid, Farooq, dan Umer, 2013). Menurut Umamah dan Hidayanti (2018), strategi menulis dan gender tidak berkorelasi secara signifikan. Temuan berbeda dilaporkan oleh Hamid, Ariani, dan Ariyanto (2013) bahwa dibandingkan dengan perempuan, mahasiswa laki-laki mengalami jauh lebih banyak kesulitan dalam menulis.

Meskipun mahasiswa laki-laki dan perempuan sama-sama mengalami kesulitan dalam menulis teks eksposisi, hasil analisis statistik menunjukkan bahwa aspek kesulitan yang mereka hadapi ternyata berbeda. Di antara empat aspek menulis, nilai rata-rata mahasiswa perempuan lebih tinggi pada dua aspek yaitu organization and content $(3,1481>2,8889)$, dan grammar $(3,6250>3,1250)$. Sedangkan mahasiswa laki-laki lebih tinggi pada dua aspek yang lain yaitu style $(3,5333>3,4000)$ dan mechanics $(2,7083>2,6250)$.

Alasan perempuan cenderung mengalami kesulitan pada aspek organization and content dan grammar bisa disebabkan oleh pendapat bahwa perempuan lebih analytic dibandingkan laki-laki. Mereka juga cenderung lebih detail dalam menulis dibandingkan laki-laki. Hal ini dibuktikan oleh penelitian Waskita (2008) yang menyebutkan bahwa struktur tulisan mahasiswa perempuan lebih kompleks. Mereka menggunakan paraphrase dalam menulis kutipan dan teks yang mereka tulis lebih terorganisasi dengan baik. Umamah dan Hidayanti (2018) juga menemukan bahwa mahasiswa perempuan lebih sering menggunakan strategi belajar menulis yang lebih fokus pada organization and content dan grammar seperti self-monitoring, planning, language-focusing, self-evaluating, socialprocessing, dan authentic-practicing strategies. Dengan kata lain, perempuan lebih fokus pada dua aspek menulis: organization and content dan grammar sehingga mereka merasa lebih kesulitan dengan dua hal itu. Sedangkan mahasiswa laki-laki lebih kesulitan dengan mechanics dan style. Hal ini menunjukkan bahwa laki-laki cenderung kurang teliti jika dibandingkan dengan perempuan (Hindal, Reid, \& Whitehead, 2013).

Berdasarkan temuan tersebut, mahasiswa perempuan harus lebih memaksimalkan penggunaan strategi belajar menulis terkait

Tabel 2 Perbedaan Kesulitan yang Dialami Mahasiswa Dilihat dari Sisi Gender

\begin{tabular}{llrrr}
\hline \multicolumn{1}{c}{ Aspek Menulis } & Kelompok & Rata-rata & $\begin{array}{c}\text { Perbedaan } \\
\text { rata-rata }\end{array}$ & Nilai t \\
\hline Organization and & Laki-laki & 2,8889 &, 25926 &, 412 \\
content & Perempuan & 3,1481 & & \\
Grammar & Laki-laki & 3,1250 &, 50000 &, 069 \\
& Perempuan & 3,6250 & &, 651 \\
Style & Laki-laki & 3,5333 &, 13333 &, 606 \\
\multirow{2}{*}{ Mechanics } & Perempuan & 3,4000 & &, 08333 \\
\hline
\end{tabular}


dengan organization and content dan grammar. Sedangkan mahasiswa laki-laki perlu diarahkan untuk menggunakan social-processing strategies untuk mendapatkan koreksi dan saran dari teman sehingga kesalahan pada aspek mechanics dan style bisa teratasi.

\section{Deskripsi Hasil Pekerjaan Subjek dalam Menulis Teks Eksposisi}

Penelitian ini mengidentifikasi kesulitan subjek terutama dalam menulis teks eksposisi. Teks yang ditulis berupa sebuah paragraf yang harus memiliki tiga komponen: kalimat topik, kalimat penjelas, dan kesimpulan. Adapun topik yang diberikan kepada subjek adalah "Do you agree with the use of Edmodo in Writing Class?" (apakah Anda setuju dengan penggunaan Aplikasi Edmodo di kelas menulis?). Subjek diminta untuk memberi pendapat mereka (setuju atau tidak setuju) dengan memberikan penjelasan tentang alasannya. Dari total 26 subjek diambil enam hasil pekerjaan subjek ( 3 dari subjek laki-laki dan 3 dari subjek perempuan) untuk dianalisis lebih mendalam. Hasil pekerjaan subjek ini merupakan draf akhir yang sudah melalui tahap konsultasi dan polishing yang terdiri dari tahap revisi dan editing.

Berikut adalah analisis detail hasil pekerjaan masing-masing subjek yang disimbolkan dengan huruf S. S1-S3 merupakan subjek dengan gender laki-laki, sedangkan S4-S6 adalah subjek yang berjenis kelamin perempuan.

Gambar 1 menunjukkan bahwa dalam hal konten dan organisasi, S1 sudah dengan lengkap menuliskan tiga komponen paragraf (kalimat

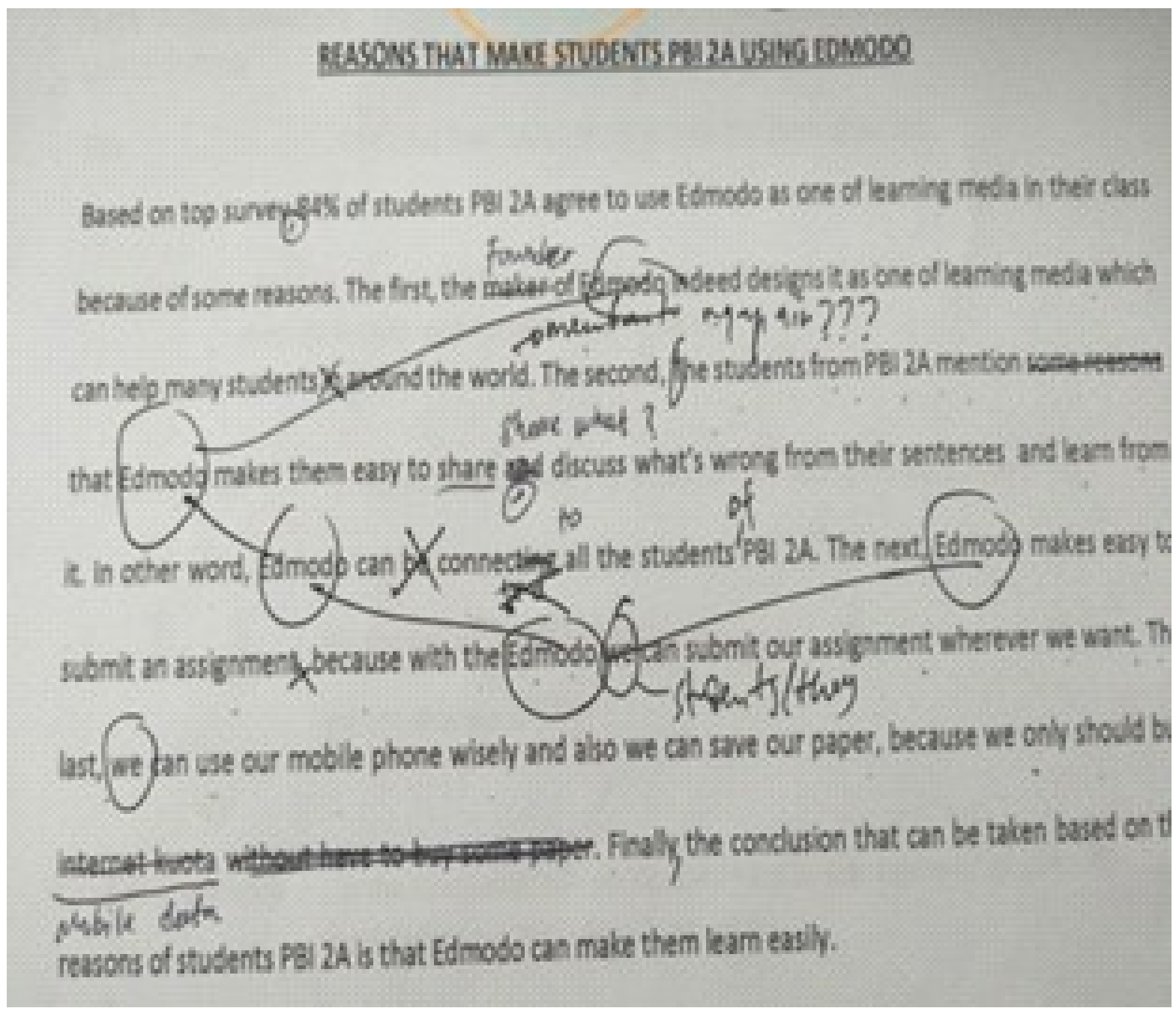

Gambar 1 Hasil Pekerjaan S1 
topik, kalimat penjelas, dan kesimpulan). Tetapi, subjek mengalami kesulitan untuk menjelaskan alasannya setuju menggunakan Edmodo. Subjek hanya mengatakan bahwa Edmodo membantu siswa di dunia, namun tidak menyebutkan secara spesifik membantu dalam hal apa. Subjek juga menyebutkan Edmodo memudahkan untuk berbagi, tetapi tidak menuliskan berbagi apa.

Dalam hal grammar, S1 mengalami kesulitan dalam menulis kalimat dengan 'modal auxiliary' can penggunaan preposition (kata depan) seperti dalam 'the students $P B I 2 A^{\prime}$ yang seharusnya diberi kata depan 'of' menjadi 'the students of PBI $2 A$ '. Dari sisi mechanics, subjek tidak memberikan tanda koma setelah pengantar kalimat seperti 'based on top survey' dan 'finally' serta menuliskan tanda koma sebelum sub clause yang diawali dengan kata hubung because. Selain itu, ada kesalahan dalam menggunakan huruf kapital pada kata 'the' yang berada di tengah kalimat. Ada pula kesalahan dalam menuliskan ejaan kata 'quota' dengan ejaan 'kuota'. Pada aspek style, kata yang digunakan S1 juga kurang bervariasi karena subjek mengulang kata Edmodo sebanyak lima kali.

Hasil pekerjaan S2 (Gambar 2) menunjukkan bahwa subjek sudah menuliskan komponen

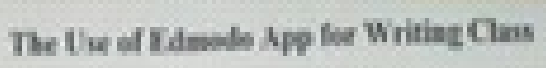

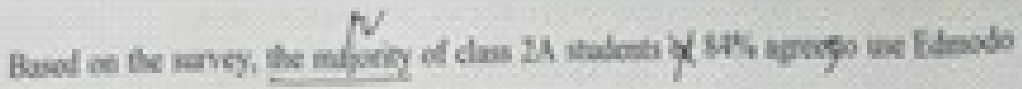

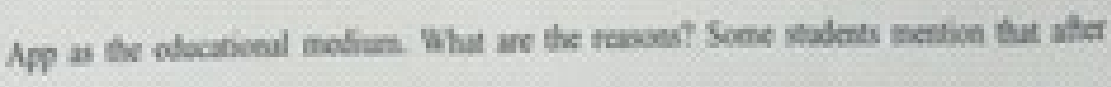

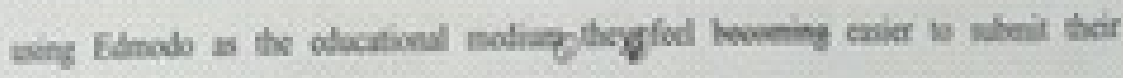

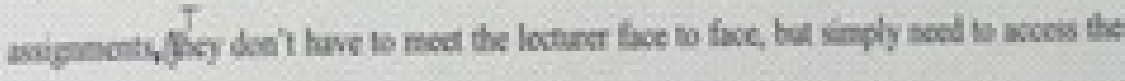

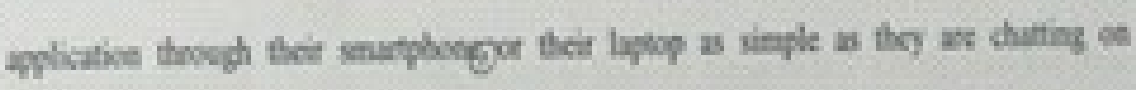

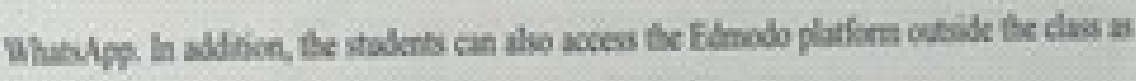

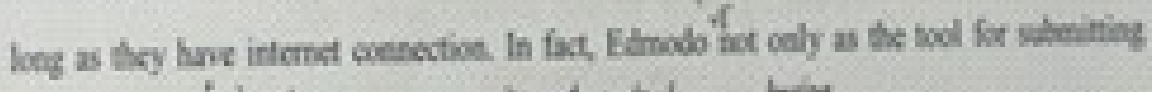

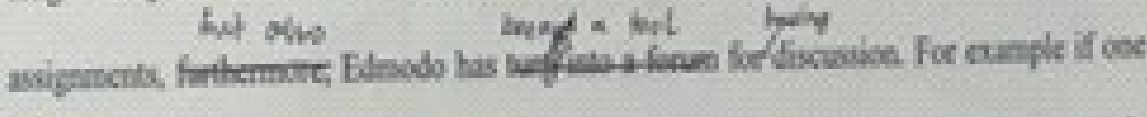

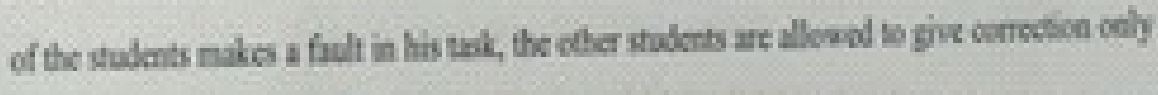

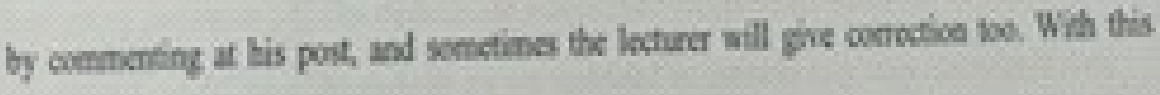

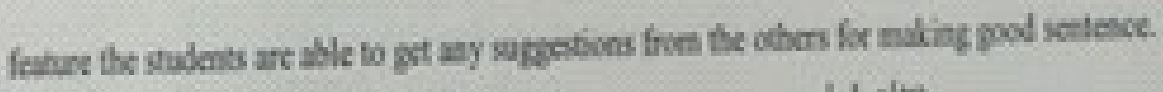

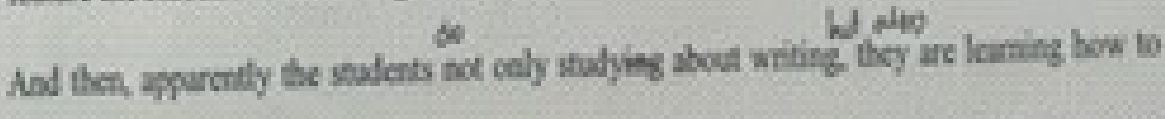

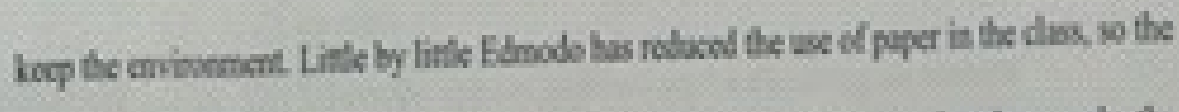

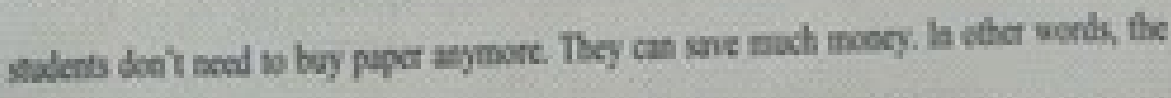

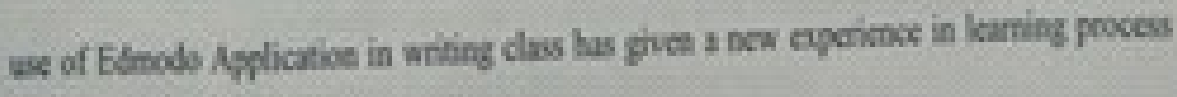

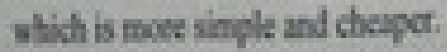


paragraf dengan lengkap dan bisa mengembangkan ide/konten dengan baik. Setiap kalimat penjelas utama (main supporting sentence) diberikan detail. Dalam hal grammar, s2 mengalami beberapa kesulitan menuliskan kata kerja bantu untuk kalimat negatif seperti 'Edmodo not only as the tool for submitting assignment ...' yang seharusnya 'Edmodo is not only ...' dan dalam kalimat '... the students not only studying ...' yang seharusnya "... the students do not only studying ...', penggunaan 'studying' setelah 'do not' juga tidak tepat karena seharusnya 'do not study'. S2 juga bermasalah dengan penggunaan preposition 'of' yang kurang tepat serta tidak tepat menggunakan paired conjunction 'not only...but also' karena subjek menggunakan kata 'furthermore'. Selain itu, S2 juga menuliskan dua kata kerja 'feel becoming easier'. Dalam hal mechanics, S2 tidak tepat dalam menuliskan tanda koma dalam compound sentence. Pada aspek style, S2 sangat baik dalam memilih kata, tetapi kalimat ketiga dari atas terlalu panjang ( 4 baris lebih) yang semestinya dijadikan dua kalimat.

Gambar 3 mendeskripsikan bahwa S3 juga sudah bisa mengembangkan ide dan mengorganisasikan paragraf dengan cukup baik meskipun penjelasan untuk main supporting sentence terakhir masih kurang detail. Pada aspek grammar terdapat satu kesalahan terkait dengan kesesuaian subjek dan kata kerja

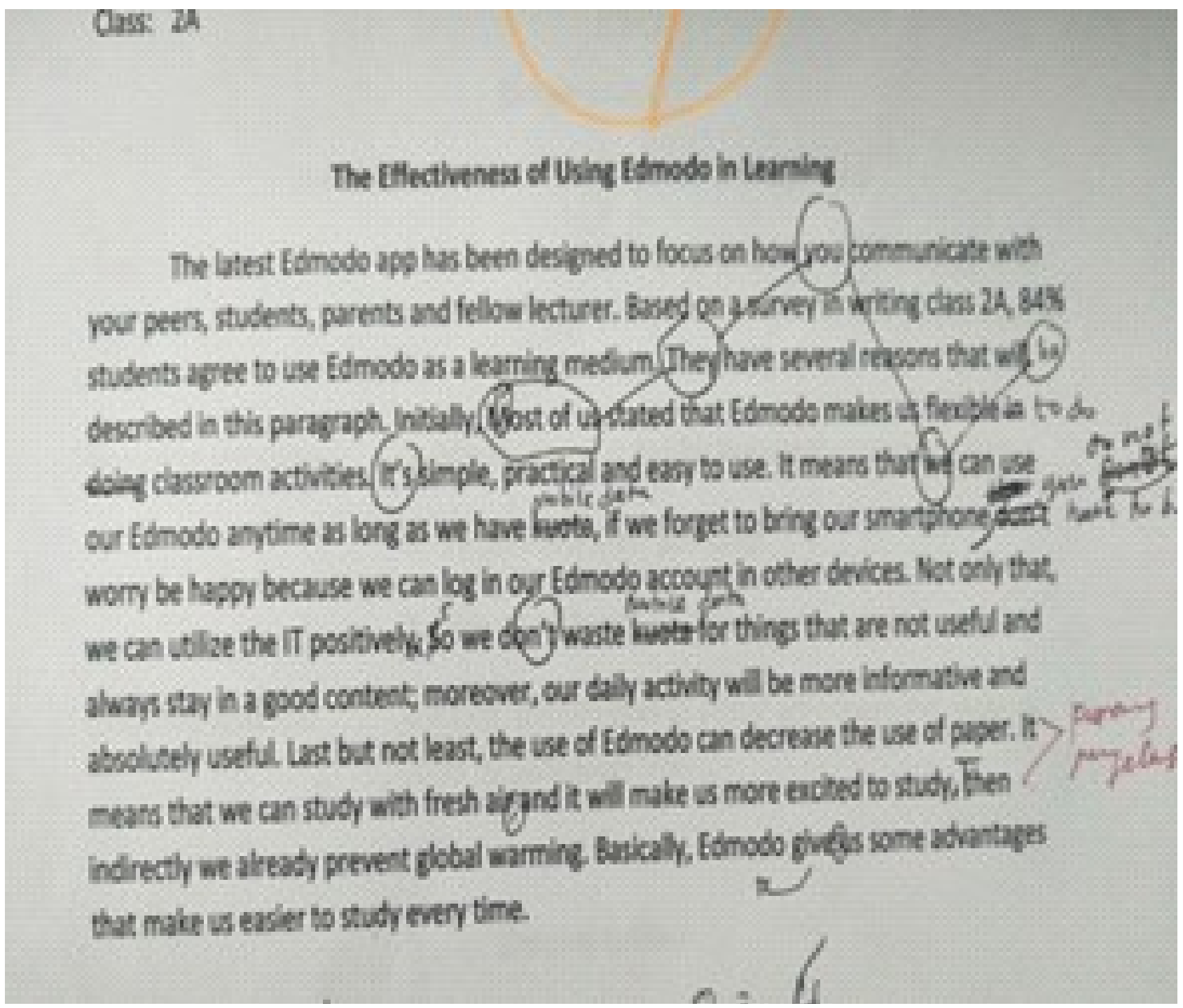

Gambar 3 Hasil Pekerjaan S3 
'Edmodo give ...' yang seharusnya 'Edmodo gives

...' karena kalimat dalam bentuk simple present tense. Kesalahan dalam mechanics antara lain salah menggunakan huruf kapital dan ejaan kata 'quota' yang ditulis 'kuota'. Dalam hal style, S3 terlihat mengalami kesulitan dalam konsistensi menulis kata ganti (most of us, you, they, we) untuk merujuk pada subjek yang sama.

Analisis hasil pekerjaan S4 (Gambar 4) adalah bahwa subjek mengalami kesulitan untuk menulis tiga komponen paragraf. Pada bagian kalimat topik, S4 menulis dua kalimat yang intinya sama. Kesimpulan juga tidak ditulis dengan tepat. Dalam konten karena terlihat jelas subjek tidak bisa mengembangkan ide dengan baik. Pada aspek grammar, kesalahan (penggunaan tenses, kalimat tidak memiliki kata kerja, kesesuaian subjek dengan kata kerja, penggunaan kata depan) yang dibuat cukup fatal karena menyulitkan pembaca untuk memahami maknanya. Mechanics juga terdapat beberapa kesalahan dalam menuliskan tanda baca (sebelum titik ada spasi), ejaan 'concluding' yang ditulis 'concludin', dan penempatan koma setelah kata hubung 'so'. Dalam hal style, S4 juga tampak hanya menulis tanpa ada variasi kalimat.

Hasil pekerjaan S5 (Gambar 5) sudah baik dalam kelengkapan komponen paragraf dan pengembangan ide yang detail. Ada beberapa kesalahan dalam grammar seperti kesesuaian subjek dan kata kerja (...the lecturer use Edmodo yang seharusnya ...the lecturer uses Edmodo), penggunaan kata depan dan dalam menyusun kalimat dengan paired conjunction 'not only...but also' yang tidak paralel. Selain

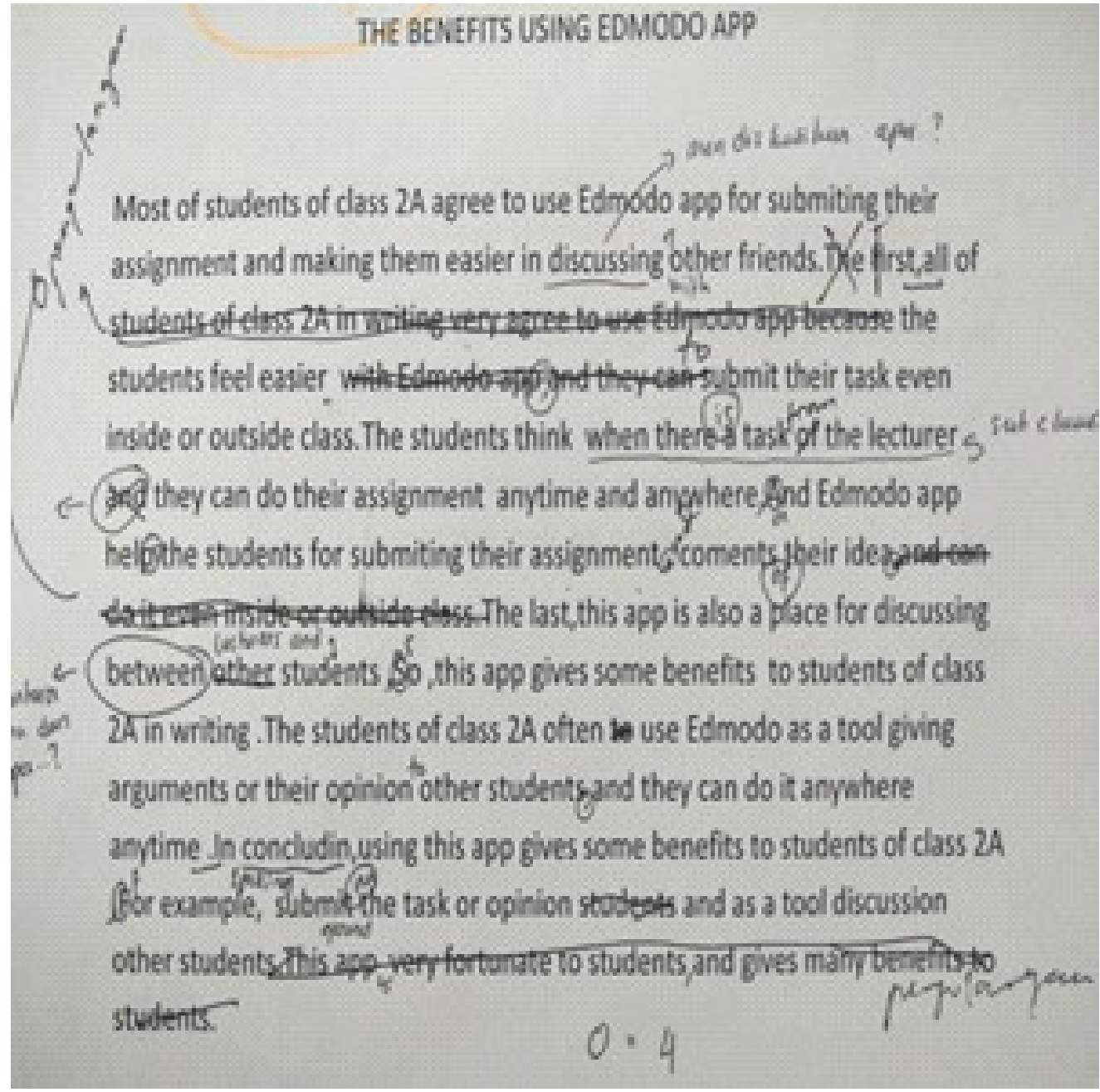

Gambar 4 Hasil Pekerjaan S4 


\section{Ving Elado Aptication b Writag Cus}

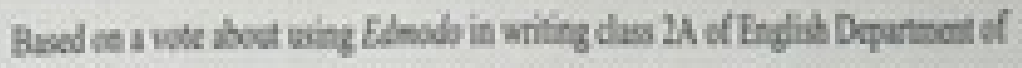

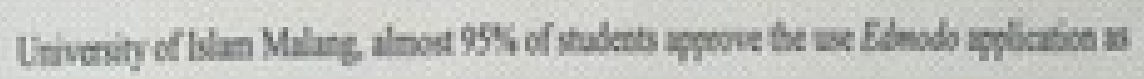

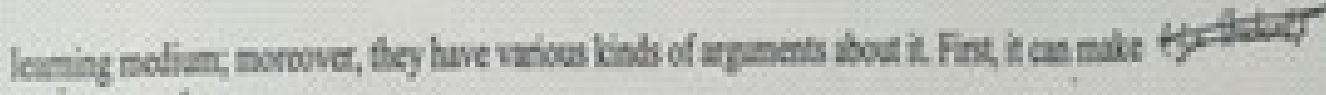

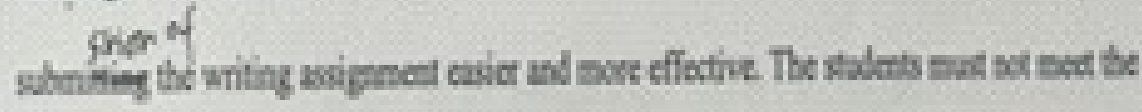

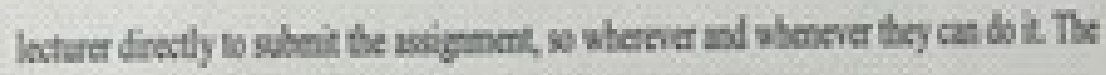

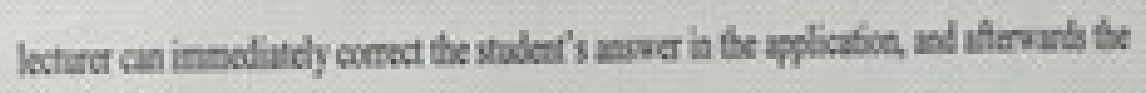

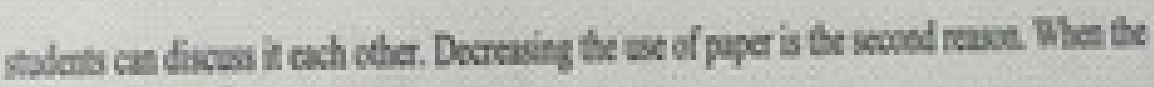

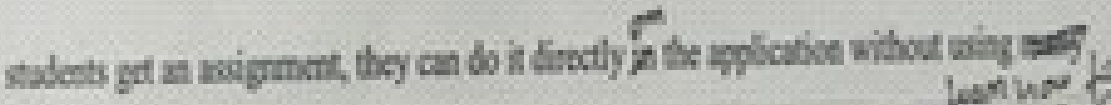

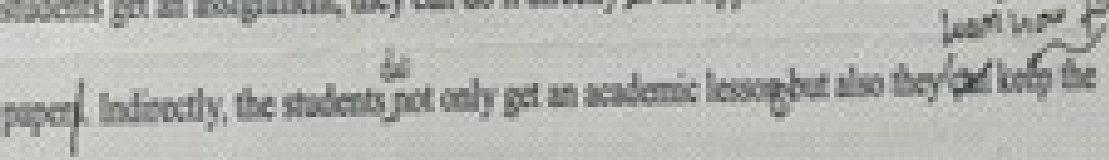

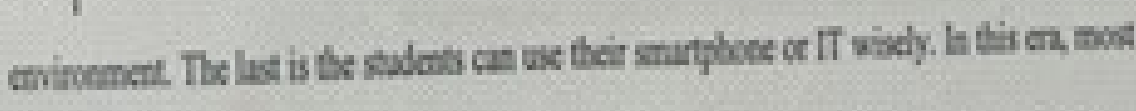

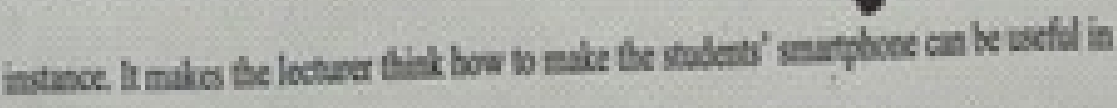

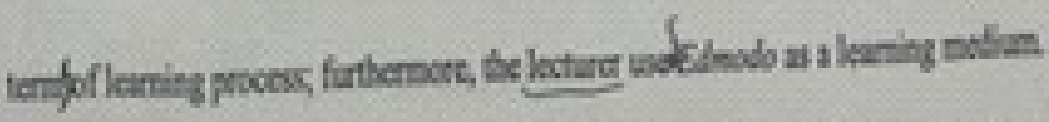

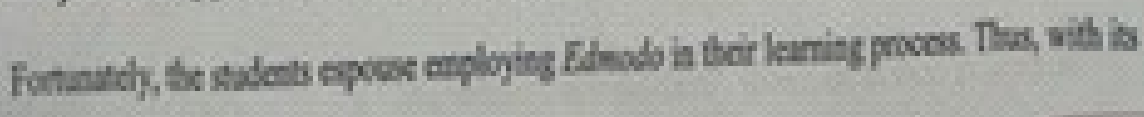

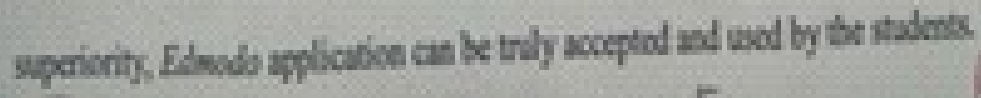

\section{Gambar 5 Hasil Pekerjaan S5}

itu, ada kesalahan dalam penggunaan kata benda tunggal yang tidak bisa dihitung 'paper' (selalu tunggal) yang ditulis 'papers' (jamak) dan kata benda 'submission' namun ditulis dalam bentuk gerund 'submitting' yang tidak sesuai konteks. Dari segi mechanics, kesalahan yang ditemukan adalah ejaan 'in terms of yang ditulis 'in term of'. Dalam hal style, secara keseluruhan sudah baik karena penggunaan kata/istilah yang tepat dan kalimat yang bervariasi.
Gambar 6 mendeskripsikan bahwa S6 sudah mampu mengorganisasikan dan mengembangkan konten dengan baik. Tiga komponen paragraf sudah lengkap dan detail untuk main supporting sentence juga sudah cukup. Pada aspek grammar, kesalahan yang muncul pada struktur penggunaan modal '...can't being lazy' yang seharusnya 'can't be lazy' dan penggunaan kata benda tunggal/jamak 'one of online application' yang kurang $s$ pada kata applications dan mobile 


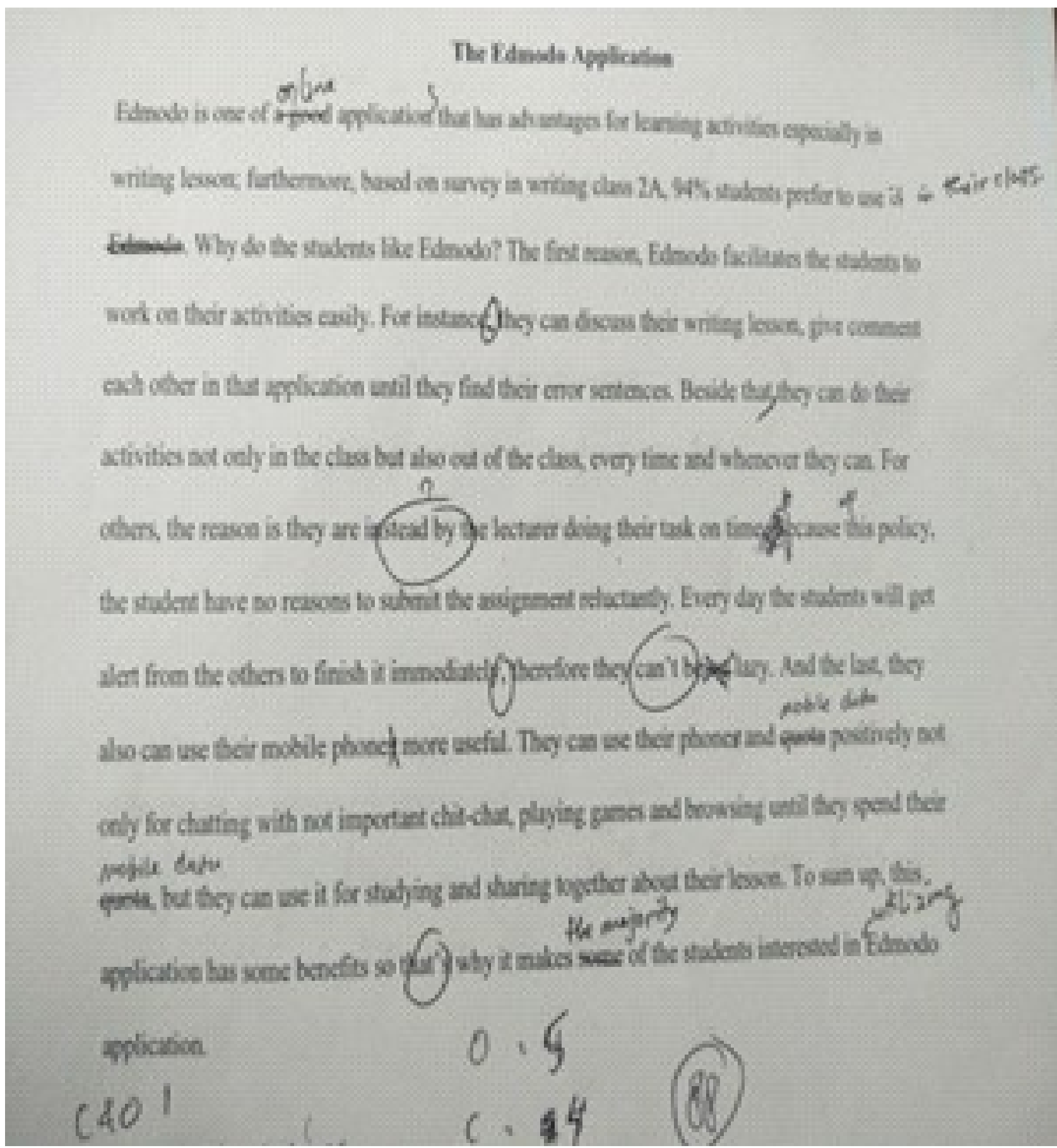

Gambar 6 Hasil Pekerjaan S6

phone yang konteksnya hanya satu tetapi ditulis dalam bentuk jamak. Kesalahan pada mechanics antara lain penggunaan titik koma yang tidak tepat setelah kata 'for instance' yang seharusnya membutuhkan tanda koma. Sebaliknya ada kesalahan pada penggunaan tanda koma sebelum conjunctive adverb 'furthermore' yang seharusnya menggunakan tanda titik koma dan setelah kata tersebut seharusnya diberi tanda koma namun tidak ada. Dalam hal style, pada dasarnya sudah ada variasi yang dilakukan tetapi ada penggunaan kata 'some' yang kurang tepat karena merujuk pada $94 \%$ dari $100 \%$ mahasiswa dan lebih tepat menggunakan kata 'the majority atau the most'.

Analisis deskriptif hasil pekerjaan subjek diringkas pada Tabel 3. Tabel 3 menunjukkan bahwa kesalahan menulis tertinggi pada aspek 
Tabel 3 Rekapitulasi Sebaran Kesalahan Mahasiswa Berdasarkan Gender Diambil dari Hasil Pekerjaan Mahasiswa

\begin{tabular}{lccccc}
\hline \multirow{2}{*}{$\begin{array}{c}\text { Aspek } \\
\text { Menulis }\end{array}$} & \multicolumn{4}{c}{ Laki-laki } & \multicolumn{3}{c}{ Gender } & \\
\cline { 2 - 5 } & $\begin{array}{c}\text { Jumlah } \\
\text { kesalahan }\end{array}$ & $\begin{array}{c}\text { Persentase } \\
(\%)\end{array}$ & $\begin{array}{c}\text { Jumlah } \\
\text { kesalahan }\end{array}$ & $\begin{array}{c}\text { Persentase } \\
(\%)\end{array}$ & \\
\hline $\begin{array}{l}\text { Content and } \\
\text { organization }\end{array}$ & 1 & 4 & 2 & 6 & 3 \\
Grammar & 12 & 43 & 16 & 47 & 28 \\
Mechanics & 9 & 32 & 10 & 29 & 19 \\
Style & 6 & 21 & 6 & 18 & 12 \\
\hline Total & 28 & 100 & 34 & 100 & 62 \\
\hline
\end{tabular}

grammar dengan total 28 kesalahan, diikuti dengan mechanics dengan 19 kesalahan, style dengan 12 kesalahan, dan content and organization dengan 3 kesalahan. Temuan ini sesuai dengan penghitungan statistik deskriptif dimana jumlah kesalahan dengan intensitas tertinggi ada pada grammar dan diikuti mechanics. Hal yang sedikit berbeda terjadi pada dua aspek lain yaitu content and organization dan style. Pada statistik deskriptif content and organization menempati posisi ketiga dan style berada pada posisi terakhir.

Tingkat kesalahan secara keseluruhan antara subjek laki-laki dan perempuan tidak jauh berbeda. Total kesalahan subjek laki-laki berjumlah 28, sedangkan subjek perempuan memiliki tingkat kesalahan lebih tinggi yaitu 34 atau selisih 6 kesalahan. Analisis hasil pekerjaan subjek ini juga mendukung hasil analisis komparatif ( $u j i \mathrm{t}$ ) yang mengindikasikan bahwa perbedaan kesalahan dalam hal gender tidak signifikan. Secara spesifik, ada sedikit perbedaan antara temuan analisis statistik dan analisis deskriptif. Analisis deskriptif menunjukkan bahwa baik subjek laki-laki maupun perempuan memiliki kesalahan tertinggi pada aspek grammar dan mechanics diikuti dengan style dan content and organization. Sementara itu, analisis statistik menemukan bahwa kesulitan yang paling sering dialami subjek perempuan pada content and organization dan grammar. Subjek laki-laki lebih mengalami kesulitan pada aspek mechanics dan style.

Temuan ini mendukung hasil penelitian Javid, Farooq, dan Umer (2013) yang meneliti hal serupa di Saudi Arabia. Penelitian tersebut mengindikasikan bahwa mahasiswa perempuan cenderung lebih mengalami kesulitan pada organization and content serta grammar, sedangkan mahasiswa laki-laki lebih kesulitan dalam hal gaya menulis dan mekanik. Temuan ini juga sesuai dengan yang dilaporkan oleh Waskita (2008), yang menyatakan bahwa perempuan lebih cenderung menulis dengan struktur yang lebih kompleks dan ide yang terorganisasi lebih baik sehingga mereka lebih merasa mengalami kesulitan dalam organization and content serta grammar.

Ong (2015) bahkan menyebutkan bahwa mahasiswa perempuan memiliki nilai tes menulis yang lebih baik dibandingkan mahasiswa lakilaki. Oleh karena itu, menurut Bijami, Kashef, dan Khaksari (2013) mahasiswa laki-laki memerlukan perhatian lebih dibandingkan mahasiswa perempuan dalam proses pembelajaran menulis agar mereka lebih termotivasi. Pada dasarnya baik mahasiswa laki-laki maupun perempuan sama-sama memiliki kendala dalam menulis dan keduanya memerlukan strategi belajar menulis yang tepat sesuai dengan kebutuhan masing-masing agar mereka dapat meningkatkan keterampilan menulis. 


\section{SIMPULAN DAN SARAN}

\section{Simpulan}

Dalam konteks bahasa Inggris sebagai bahasa asing, menulis menjadi jauh lebih kompleks. Mahasiswa tidak hanya berhadapan dengan kendala dalam menulis ide/konten. Mereka juga dihadapkan pada kesulitan dalam hal keakuratan bahasa (language accuracy) terutama grammar dan mechanics. Hal ini disebabkan oleh perbedaan sistem/struktur dan latar belakang budaya (cultural background) antara bahasa pertama (L1) dengan bahasa target (L2/Bahasa Inggris).

Berkaitan dengan temuan bahwa perbedaan kesulitan menulis berdasarkan gender tidak signifikan, hal ini menunjukkan bahwa gender bukanlah satu-satunya variabel yang berkontribusi terhadap kesulitan menulis atau kualitas tulisan. Hal ini juga mengindikasikan bahwa baik mahasiswa laki-laki maupun perempuan mengalami kesulitan dalam menulis, tetapi berbeda pada aspek dan level kesulitan. Pada dasarnya mahasiswa juga dapat mengidentifikasi kesulitan mereka dalam menulis tetapi mereka belum mengetahui strategi yang tepat untuk mengatasi kesulitan tersebut.

\section{Saran}

Implikasi temuan penelitian ini adalah pentingnya mengintegrasikan pengajaran grammar dalam kelas menulis dengan porsi secukupnya sehingga tidak akan mendominasi pembelajaran menulis itu sendiri. Meskipun pada penelitian ini tingkat perbedaan kesulitan tidak signifikan, memperhatikan gender dalam proses pembelajaran juga akan memberikan dampak yang cukup signifikan. Selain itu, mahasiswa perlu mendapatkan pemahaman akan pentingnya strategi belajar dalam proses pembelajaran untuk mengatasi kesulitan yang mereka hadapi dalam menulis. Sebagaimana disimpulkan oleh Zuhairi dan Umamah (2016), mengimplementasikan strategies-based instruction (SBI) dalam kelas menulis menjadi alternatif solusi untuk bisa membantu mahasiswa menulis dengan lebih baik.

\section{PUSTAKA ACUAN}

Al Seyabi, F. \& Tuzlukova, V. (2014). Writing problems and strategies: An investigative study in the Omani school and university context. Asian Journal of Social Sciences \& Humanities, 3(4),37-48.

Aminullah, R. \& Sahidol, J.N.M. (2016). Reading and writing connection in ESP context: Students' performance and perceptions. In: Abdullah M., Yahya W., Ramli N., Mohamed S., Ahmad B. (eds) Regional Conference on Science, Technology and Social Sciences (RCSTSS 2014). Springer, Singapore. doi: https://doi.org/10.1007/978-981-10-1458-1_40

Ariyanti. (2016). The teaching of EFL writing in Indonesia. Dinamika IImu, 16(2),263-277.

Bijami, M., Kashef, S.H., \& Khaksari, M. (2013). Gender differences and writing performance: A brief review. International Journal of Education \& Literacy Studies, 1(2),8-11. doi: $10.7575 / a i a c . i j e l s . v .1 n .2 p .8$.

Brown, H. D. (2007). Teaching by principles: An interactive approach to language pedagogy (3rd ed.). New York: Pearson Education, Inc.

Fareed, M., Ashraf, A., \& Bilal, M. (2016). ESL learners' writing skills: Factors dan suggestions. Journal of Education and Social Sciences, 4(2),81-92. doi: 10.20547/jess0421604201.

Hamid, S., Ariani, M., \& Ariyanto, S. (2013). An analysis on the gender-based difference of the eight year students' recount paragraph writing based on the grammatical errors at SMPN 3 Jenggawah Jember. Pancaran, 2(2),75-84. 
He, T.-H., Chang, S.-M., \& Eileen Chen, S.H. (2011). Multiple goals, writing strategies, and written outcomes for college students learning English as a second language. Perceptual and Motor Skills, 112(2), 401-416. doi: https://doi.org/10.2466/11.21.28.PMS.112.2.401416.

Hindal, H., Reid, N., \& Whitehead, R. (2013). Gender and Learner Characteristics. European Journal of Educational Research, 2(2), 83-96. doi:10.12973/eu-jer.2.2.83.

Javid, C.Z., Farooq, U., \& Umer, M. (2013). An investigation of Saudi EFL learners' writing problems: A case study along gender-lines. Kashmir Journal of Language Research, 16(1), 179-203.

Karim, S. M. S., Maasum, T. N. R. T. M., \& Latif, H. (2017). Writing challenges of Bangladeshi tertiary level EFL learners. Journal of Social Science and Humanities, 12(2), 296-306.

Jennifer J.M., \& Ponniah, R.J. (2018). Acquisition of writing by reading and its impact on cognition. In: Ponniah R., Venkatesan S. (eds) The Idea and Practice of Reading. Singapore: Springer. doi: https://doi.org/10.1007/978-981-10-8572-7_4.

Mistar, J. (2011). Learning strategies by Indonesian senior high school EFL learners. Korea TESOL Journal, 10(1), 52-74.

Mistar, J., Zuhairi, A., \& Parlindungan, F. (2014). Strategies of learning writing skill by Indonesian senior high school students. AWEJ, 5(1), 290-303.

Mohammad, T. \& Hazarika, Z. (2016). Difficulties of learning EFL in KSA: Writing skills in context. International Journal of English Linguistics, 6(3), 105-117 doi:10.5539/ijel.v6n3p105.

Munoz-Luna, R. (2015). Main ingredients for success in L2 academic writing: Outlining, drafting, and proofreading. PIoS ONE, 10(6), 1-15. doi:10.1371/journal.pone.0128309

Okasha, M. A. \& Hamdi, S. A. (2014). Using strategic writing techniques for promoting EFL writing skills and attitudes. Journal of Language Teaching and Research, 5(3) 674-681, doi: $10.4304 /$ jltr.5.3.674-681

Ong, J. (2015). Do individual differences matter to learners' writing ability? The Asian Journal of Applied Linguistics, 2(2),129-139.

Oshima, A. \& Hogue, A. (2007). Introduction to academic writing. $3^{\text {rd }}$ ed. New York: Pearson Education.

Raoofi, S., Binandeh, M., \& Rahmani, S. (2017). An investigation into writing strategies and writing proficiency of university students. Journal of Language Teaching and Research, 8(1),191-198. doi: http://dx.doi.org/10.17507/jltr.0801.24

Schoonen, R. (2018). Are reading and writing building on the same skills? The relationship between reading and writing in L1 and EFL. Reading and Writing, June. doi.org/10.1007/ s11145-018-9874-1.

Umamah, A. \& Hidayanti, I. (2018). Writing strategy and factors contributing to EFL university students' preference. ELT-Echo, 3(3), 70-76, ,http://www.syekhnurjati.ac.id/jurnal/ index.php/eltecho/article/view/2486https://www.researchgate.net/publication/ 327138706.

Waskita, D. (2008). Differences in men's and women's ESL academic writing at The University of Melbourne. Jurnal Sosioteknologi, 7(14), 448-463. 
Wigati, S. A. (2014). Kesulitan pada aspek-aspek writing mahasiswa dengan English proficiency levels yang berbeda. Jurnal IImiah Solusi, 1(3), 46-61.

Yahya, M. Y. \& Hashim, N. H. (2013). Difficulties and ways to improve english writing skills among postgraduate ESL Students. 6th International Conference of Education, Research and Innovation (ICERI2013 Proceedings). IATED, Seville, Spain.

Zuhairi, A. \& Umamah, A. (2016). The Indonesian junior high school students' strategies in learning writing skill. Arab World English Journal, 7 (3), 385-393. doi:https://dx.doi.org/ 10.24093/awej/vol7no3.27. 